\title{
Hak Asuh Anak Akibat Perceraian dalam Pandangan Ulama Pedesaan
}

\author{
Ila Nurmila \\ Institut Agama Islam Darussalam (IAID) Ciamis, Jawa Barat \\ Email: ila.nurmilacms@gmail.com \\ Azmi Azizah \\ Institut Agama Islam Darussalam (IAID) Ciamis, Jawa Barat \\ Robi Awaludin \\ Institut Agama Islam Darussalam (IAID) Ciamis, Jawa Barat
}

\begin{abstract}
ABSTRAK
Salah satu tujuan dari perkawinan adalah untuk membentuk keluarga yang sakinah, mawaddah warahmah. Namun demikian didalam perjalanan hidup berkeluarga tidak selalu berjalan dengan mulus terkadang menemui hambatan, tidak jarang persoalan dan perselisihan antara suami isteri berakhir dengan perceraian. Dan perceraian merupakan obat yang sangat pahit yang hanya digunakan untuk mengobati penyakit rumah tangga yang sudah tidak bisa dipertahankan lagi sehingga tidak ada obat selain perceraian yang dapat menyembuhkannya. Perceraian yang mana dapat melantarkan status anak yang menjadi kewajiban suami atau istri. Putusnya pernikahan karena perceraian akan menimbulkan berbagai akibat, baik bagi isteri, suami, terutama bagi anak-anak. Perceraian menimbulkan berbagai soal terhadap kelangsungan pemeliharaan pendidikan serta pembiayaan kebutuhan anak. Kondisi ini sangat menarik bagi penulis untuk mengetahui lebih jauh tentang hak asuh anak dari hasil perceraian dan bagaimana pula menurut pendapat ulama Desa Karangampel Kecamatan Baregbeg Kabupaten Ciamis.
\end{abstract}

\begin{abstract}
One of the purposes of marriage is to form a sakinah, mawaddah warahmah family. However, in the course of family life does not always run smoothly sometimes encounter obstacles, not infrequently the problems and disagreements between husband and wife ended in divorce. And divorce is a very bitter drug that is only used to treat household diseases that can not be maintained again so there is no drug other than divorce that can cure it. Divorce which can deliver the status of the child that becomes the obligation of husband or wife. The breakup of marriage due to divorce will result in various consequences, both for wife, husband, especially for children. Divorce raises questions about the continuity of education maintenance and
\end{abstract}


the financing of children's needs. This condition is very interesting for writer to know more about child custody of result of divorce and how also according to opinion of cleric of Karangampel Village District of Baregbeg Regency of Ciamis.

Keywords: Child custody, divorce, rural ulema

\section{PENDAHULUAN}

Agama Islam adalah agama yang paling sempurna dan merupakan agama yang sempurna pula bagi kelangsungan hidup manusia dalam mencapai kemuliaan dan kebahagiaan didunia dan akhirat. Allah menciptakan makhluk hidup yang ada dimuka bumi ini beraneka ragam, ada manusia, hewan dan tumbuh-tumbuhan. Dari sekian banyak ciptaan Allah tersebut manusia adalah sebagai makhluk ciptaan Allah yang paling sempurna. Manusia adalah makhluk sosial (homo socius) artinya ia tidak dapat hidup menyendiri tanpa berinteraksi dengan manusia lainnya

Dalam perjalanan sejarah ternyata menjadi manusia bukan hanya saling kenal-mengenal saja, tetapi juga saling membutuhkan dengan kecenderungan untuk membina keluarga, membentuk rumah tangga sakinah, mawaddah wa rahmah yang ditandai dengan lembaga perkawinan. Dalam bentuknya yang sederhana lembaga perkawinan ini tumbuh dan berkembang sejak manusia pertama diciptakan.

Dalam Islam lembaga perkawinan bukan hanya sekedar pintu untuk melakukan hasrat kemanusiaan secara biologis tetapi juga mempunyai nilai ibadah dan mempunyai dampak yang sangat luas dalam pembinaan hidup bermasyarakat. Banyak sosiolog mengatakan bahwa berhasil tidaknya membina masyarakat sangat ditentukan oleh masalah perkawinan yang merupakan salah satu faktor di antara beberapa faktor lainnya. Dengan kata lain bahwa kegagalan dalam membina rumah tangga (perkawinan) bukan saja membahayakan kehidupan rumah tangga itu sendiri tetapi juga berpengaruh kepada kehidupan masyarakat. Perkawinan merupakan salah satu asas pokok hidup dalam pergaulan masyarakat yang sempurna juga keluarga merupakan bagian terkecil dari suatu negara, oleh karena itu Islam memberikan perhatian serius mengenai masalah perkawinan sebagaimana disebutkan dalam Q.S An-Nisaa ayat 21 bahwa perkawinan adalah miitsâqan ghalidzan (perjanjian yang luhur). Dalam kehidupan bermasyarakat masalah perkawinan mendapat perhatian secara khusus karena disadari bahwa kehidupan bernegara dan bermasyarakat sangat dipengaruhi oleh sistem keluarga atau perkawinan sehingga disusunlah aturan-aturan mengenai tata cara perkawinan.

Pernikahan merupakan suatu cara yang dipilih Allah sebagai jalan bagi manusia untuk mempertahankan keturunan, berkembang biak dan 
kelestarian hidupnya, setelah masing-masing pasangan siap melakukan perannya yang positif dalam mewujudkan pernikahan (Sabiq, 1990:9).

Menurut Undang-Undang No. 1 tahun 1974 tentang Perkawinan pada Bab I Dasar Perkawinan Pasal 1 dinyatakan bahwa: "Perkawinan ialah ikatan lahir batin antara seorang pria dengan seorang wanita sebagai suamiistri dengan tujuan membentuk keluarga (rumah tangga) yang bahagia dan kekal berdasarkan Ketuhanan Yang Maha Esa “ (Anonimous, 2004:8).

Salah satu tujuan pernikahan adalah membangun rumah tangga untuk mendapatkan keturunan yang sah, yang mampu mewujudkan generasi baru untuk melangsungkan kehidupan manusia, baik buruknya generasi tersebut sangat ditentukan oleh pemeliharaan dan pendidikan rohani dan jasmani.

Salah satu lingkungan yang sangat mempengaruhi perkembangan manusia adalah keluarga. Oleh karena itu orang tua terutama ayah dan ibu memiliki tanggung jawab yang sangat besar terhadap kelangsungan pemeliharaan dan pendidikan anak. Dalam hal ini ajaran Islam memberikan pedoman bagaimana besarnya tanggung jawab orang tua terhadap pemeliharaan dan pendidikan anak, seperti dijelaskan dalam sebuah hadis riwayat Imam Muslim sebagai berikut:

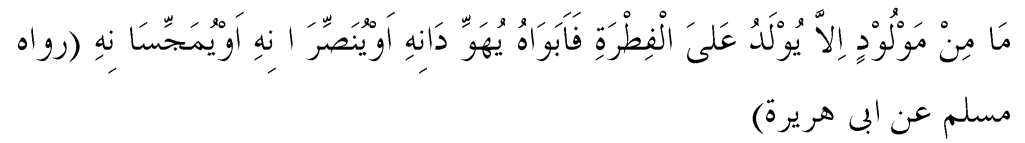

“ Tidaklah anak yang dilahirkan itu kecuali telah membawa fitrah. Maka kedua orang tuanyalah yang menjadikan anak tersebut Yahudi, Nasrani dan Majusi".

Bahwa setiap manusia dari sejak lahir memiliki kemungkinan untuk berkembang ke arah mana anak itu berkembang, itu tergantung kepada pemeliharaan dan pendidikan serta bimbingan orang tuanya. Oleh karena itu orang tualah yang paling bertanggungjawab dalam mengembangkan eksistensi anak, baik kebutuhan fisik maupun kebutuhan mental sehingga anak tumbuh dan berkembang ke arah kepribadian yang harmonis dan matang.

Indonesia sebagai suatu negara telah pula mempunyai peraturan perundang-undangan tentang perkawinan yang berlaku secara nasional yaitu Undang-undang Nomor 1 Tahun 1974 sebagaimana disebutkan dalam pasal 1 Undang-undang tersebut bahwa perkawinan adalah ikatan lahir bathin antara seorang pria dan seorang wanita sebagai suami isteri dengan tujuan membentuk keluarga (rumah tangga) yang bahagia dan kekal berdasarkan Ketuhanan Yang Maha Esa. 
Namun demikian didalam perjalanan hidup berkeluarga tidak selalu berjalan dengan mulus terkadang menemui hambatan, rintangan dan gangguan yang pada tahapan tertentu bukan saja menimbulkan kegoncangan dalam perkawinan dan rumah tangga, tetapi sering kali menimbulkan kegagalan dan kehancuran. Jika ikatan lahir bathin dan atau perjanjian luhur dalam suatu perkawinan sudah mulai memudar dan bahkan menemui kehancuran yang mengakibatkan pecahnya rumah tangga, maka Islam dan juga peraturan perundang-undangan memberikan jalan keluar yaitu dengan adanya perceraian.

Dalam Islam perceraian adalah suatu akad yang halal tetapi dimurkai Allah sebagaimana disebutkan dalam sebuah hadits yang artinya " Dari Ibnu Umar, Katanya, telah berkata Rasulullah SAW: Barang yang halal yang amat dibenci Allah yaitu Thalaq" (H.R. Ibnu Daud dan Ibnu Majah).

Dengan demikian sebisa mungkin perceraian harus dihindari. Sejalan dengan itu Undang-undang Nomor 1 Tahun 1974 tentang perkawinan yang salah satu prinsipnya menganut prinsip mempersulit perceraian yaitu dengan berusaha semaksimal mungkin dapat mengendalikan dan menekan angka perceraian kepada titik yang paling rendah. Perceraian yang dilakukan tanpa kendali dan sewenang-wenang dengan dalih bahwa perceraian itu hak suami yang hanya cukup dengan kata-kata "aku talak engkau" atau hanya sekedar dengan sindiran "aku kembalikan engkau kepada orang tuamu". Pemikiran dan tata cara demikian itu harus segera dirubah dan dihilangkan dalam masyarakat. Hak cerai tidak hanya dipegang oleh suami saja tetapi isteripun dapat menggugat suami untuk bercerai jika ada hal-hal yang menurut keyakinannya rumah tangga yang dibina itu tidak mungkin dapat diteruskan atau dibina lagi.

Kewajiban memelihara dan mendidik anak hanya dapat dilaksanakan dengan sebaik-baiknya jika hubungan perkawinan keduanya baik, sehingga suami istri menjadi satu kesatuan yang utuh, suasana keluarga penuh kasih sayang dan keakraban, saling pengertian, persahabatan dan saling menghargai.

Tetapi hubungan suami isteri dalam suatu pernikahan tidak selamanya berjalan dengan mulus, tidak jarang persoalan dan perselisihan antara suami isteri berakhir dengan perceraian. Dan perceraian merupakan obat yang sangat pahit yang hanya digunakan untuk mengobati penyakit rumah tangga yang sudah tidak bisa dipertahankan lagi sehingga tidak ada obat selain perceraian yang dapat menyembuhkannya.

Apabila dalam pelaksanaan hak dan kewajiban masing-masing terlaksana secara terarah dan baik maka dapat dihindari permasalahan rumah tangga, namun jika hak dan kewajiban tidak dapat terpenuhi secara 
baik maka dapat terjadi keretakan dalam rumah tangga yaitu perceraian yang dapat melantarkan anak yang menjadi tanggug jawab orang tuanya.

Putusnya pernikahan karena perceraian akan menimbulkan berbagai akibat, baik bagi isteri, suami, terutama bagi anak-anak. Perceraian menimbulkan berbagai persoalan bagi kelangsungan pemeliharaan pendidikan serta kebutuhan pembiayaan anak.

\section{LANDASAN TEORITIS}

\section{Konsep Perkawinan}

Perkawinan atau pernikahan adalah suatu akad antara seorang calon mempelai laki-laki dan calon mempelai wanita atas dasar kerelaan dan kesukaan kedua belah pihak, yang dilakukan oleh pihak lain (wali) menurut sifat dan syarat yang telah ditetapkan oleh syara untuk menghalakan percampuran antara keduanya, sehingga satu sama lain saling membutuhkan menjadi sekutu sebagai teman hidup dalam rumah tangga (Saebani, 2009:14).

Perkawinan atau pernikahan dalam literatur fiqih berbahasa Arab disebut dengan dua kata, yaitu "nikah" dan "zawaj". Kedua kata ini yang terpakai dalam kehidupan sehari-hari orang Arab dan banyak terdapat dalam Al-Qur'an dan contoh hadits Nabi (Syarifuddin, 2006:36). Kata nakaha banyak terdapat dalam Al-Qur'an dengan arti kawin seperti dalam Q.S. AnNisaa, ayat 3, "Dan jika kamu takut tidak akan dapat berlaku adil terhadap (hak-hak) perempuan yang yatim (bilamana kamu mengawininya), maka kawinilah wanita-wanita (lain) yang kamu senangi: dua, tiga atau empat. Kemudian jika kamu takut tidak akan dapat berlaku adil. Maka (kawinilah) seorang saja, atau budak-budak yang kamu miliki. Yang demikian itu adalah lebih dekat kepada tidak berbuat aniaya". (QS. An-Nisaa, 04:3).

Menurut Undang-Undang No. 1 tahun 1974 tentang Perkawinan pada Bab I Dasar Perkawinan Pasal 1 dinyatakan bahwa: "Perkawinan ialah ikatan lahir batin antara seorang pria dengan seorang wanita sebagai SuamiIstri dengan tujuan membentuk keluarga (rumah tangga) yang bahagia dan kekal berdasarkan Ketuhanan Yang Maha Esa “ (Anonimus, 2004:8).

Dalam Kompilasi Hukum Islam pengertian pernikahan yaitu disebut dengan perkawinan, seperti dijelaskan dalam pasal 2 BAB II (Dasar-dasar perkawinan), bahwa yang dimaksud perkawinan yaitu akad yang sangat kuat atau mitsaaqon ghaliizhan untuk mentaati perintah Allah dan melakukannya merupakan ibadah. Perkawinan bertujuan untuk mewujudkan kehidupan rumah tangga yang sakinah, mawaddah, dan rahmah (pasal 3). Hal ini sesuai dalam firman Allah Q.S Ar-Ruum ayat 21, "Dan di antara tanda-tanda (kebesaran)-Nya ialah Dia menciptakan pasangan- 
pasangan untukmu isteri-isteri dari jenismu sendiri, agar kamu cenderung dan merasa tenteram kepadanya, dan Dia menjadikan diantaramu rasa kasih dan sayang. Sungguh, pada yang demikian itu benar-benar terdapat tanda-tanda (kebesaran Allah) bagi kaum yang berfikir". (Q.S. Ar-Ruum, 30:21)

Sedangkan menurut syara nikah ialah "akad yang menghalalkan pergaulan antara laki-laki dan wanita yang tidak ada hubungan mahram, sehingga terjadi hak dan kewajiban antara keduanya" ( Zainuddin dan Jamhari, 1999:29). Maka dapat disimpulkan bahwa perkawinan adalah hubungan yang sah antara seorang laki-laki dan perempuan yang diakui oleh negara dan berlangsung untuk selamanya, selama mereka masih hidup.

1. Dasar hukum perkawinan

Perkawinan adalah suatu perbuatan yang disuruh oleh Allah dan juga disuruh oleh Rasulullah. Banyak suruhan-suruhan Allah dalam AlQur'an untuk melangsungkan perkawinan, diantaranya dalam firman Allah Q.S An-Nûr, ayat 32, "Dan kawinkanlah orang-orang yang sendirian diantara kamu, dan orang-orang yang layak (berkawin) dari hamba-hamba sahayamu yang lelaki dan hamba-hamba sahayamu yang perempuan. Jika mereka miskin Allah akan memampukan mereka dengan karunia-Nya dan Allah Maha Luas (pemberian-Nya) lagi Maha Mengetahui". (Q.S An-Nûr, 24:32).

Akan tetapi jika dilihat pada kondisi seseorang, maka nikah bisa berbeda pada setiap orang. Nikah diwajibkan pada seseorang, apabila memang dia mampu lahir batin dan merasa khawatir akan berbuat zina jika ia tidak menikah. Kemudian jika seseorang sudah mampu lahir dan batin untuk nikah, tetapi tanpa nikah dia tidak khawatir akan melakukan perbuatan yang diharamkan (seperti zina), maka disunahkan baginya untuk menikah. Jika perkawinan itu dilakukan oleh seorang laki-laki dengan seorang wanita dengan tujuan untuk menzalimi perempuan tersebut dengan melepaskan tanggung jawab lahir dan batin, maka bagi orang ini haram untuk menikah.

Jika lelaki itu melepaskan tanggung jawabnya dalam nafkah lahir dan batin, sementara pihak istri tidak merasa teraniaya dengan sikap itu, maka terhadap lelaki tersebut makruh hukumnya untuk menikah. Jika keinginan untuk kawin tidak begitu kuat sementara halangan untuk kawin pun tidak ada, maka hukum kawin ketika itu dikatakan ibadah (boleh) saja.

\section{Tujuan perkawinan}

Tujuan perkawinan adalah membentuk keluarga, atau rumah tangga yang bahagia dan kekal berdasarkan Ketuhanan Yang Maha Esa (Pasal 1 UU No.1 tahun 1947). Tujuan perkawinan yang diinginkan dalam UU Perkawinan No. 1 tahun 1947 bila kita rasakan adalah adalah sangat ideal 
karena tujuan perkawinan itu tidak hanya melihat dari segi lahiriah saja tetapi sekaligus terdapat adanya suatu pertautan batin antara suami dan istri yang ditujukan untuk membina suatu suatu keluarga yang kekal dan bahagia bagi keduanya dan yang sesuai dengan kehendak Tuhan Yang Maha Esa.

Tujuan pernikahan yang lain adalah memperoleh keturunan yang baik. Pembinaan akhlak manusia sehingga hubungan yang terjadi antara dua gender yang berbeda dapat membangun kehidupan baru secara sosial dan kultural. Sedikitnya ada empat macam yang menjadi tujuan perkawinan, yaitu: a). menentramkan jiwa, b). mewujudkan (melestarikan) turunan, c) memenuhui kebutuhan biologis, d). Latihan memikul tanggung jawab.

Tujuan pernikahan sejati dalam Islam adalah pembinaan akhlak manusia sehingga hubungan yang terjadi antara dua gender yang berbeda dapat membangun kehidupan baru secara sosial dan kultural. Hubungan dalam bangunan tersebut adalah kehidupan rumah tangga dan terbentuknya generasi keturunan manusia yang memberikan kemaslahatan bagi masa depan masyarakat dan dunia.

Dalam kenyataannya tidak semua perkawinan dapat berlangsung dengan langgeng dan tentunya tidak ada seorang pun yang ingin perkawinannya berakhir dengan jalan perceraian. Namun apa daya, saat semua upaya dikerahkan untuk menyelamatkan suatu perkawinan ternyata pada akhirnya diputus cerai oleh pengadilan. Dengan putusnya suatu perkawinan berdasarkan putusan pengadilan yang telah berkekuatan hukum tetap, maka akan ada akibat-akibat hukum yang mengikutinya, salah satunya adalah mengenai hak asuh atas anak-anak yang lahir dari perkawinan tersebut.

\section{Hikmah Perkawinan}

Hikmah yang terkandung dalam perkawinan menurut Zainuddin dan Jamhari (1999:32) antara lain:

1) Melaksanakan perintah agama. Nikah merupakan perintah agama yang harus dilakukan oleh laki-laki dan wanita yang siap menikah karena pernikahan adalah separuh agama. Dengan demikian, melaksanakan nikah berarti telah melaksanakan ibadah kepada Allah dan bertakwa kepada-Nya karena nikah telah menyempurnakan separuh agama.

2) Penyaluran naluri seksual secara benar dan sah, karena adakalanya naluri seksual itu sulit untuk dibendung dan sulit untuk merasa terpuaskan. Dengan jalan nikah naluri seksual dapat disalurkan kapan saja, asal hal tersebut tidak dilakukan pada waktu dan tempat yang dilarang syariat Islam. 
3) Menghindarkan perbuatan dosa dan maksiat seperti zina. Nikah menjaga manusia dari perbuatan dosa yaitu zina. Zina merupakan jalan yang buruk dan perbuatan berdosa yang dapat menyebabkan berbagai penyakit bagi orang yang melakukan zina. Dengan nikah maka manusia terhindar dari dosa dan penyakit seksual yang menular.

4) Menentramkan lahir dan batin, laki-laki merupakan benteng keamanan yang dapat dipercaya yang penuh cinta kasih tempat wanita mencari ketentraman lahir dan batin. Wanita merupakan tempat subur yang sejuk dengan rasa cinta dan kasih sayang.

5) Mendorong agar bekerja giat untuk mencari nafkah, laki-laki yang menikah dengan teman hidup yang salehah, akan bekerja keras dalam kehidupan untuk memenuhi kebutuhan hidup keluarganya dengan penuh ketabahan dan kesabaran dengan hati senang. Kemudian akan menumbuhkan rasa tanggung jawab, yang memberikan dampak terhadap aktivitas kehidupan seseorang untuk mencari nafkah.

6) Membentuk generasi penerus keluarga dan penerus agama, laki-laki dan wanita yang menikah akan melahirkan keturunan yang sah. Nikah akan memelihara dan melestarikan keturunan tiap-tiap keluarga sebagai penerus keluarga sehingga tidak tercampur baur antara satu keluarga dengan keluarga lain. Nikah juga akan membentuk generasi penerus agama karena orang tua yang sah akan memberikan pendidikan agama kepada anak-anaknya dengan baik.

\section{Konsep Perceraian}

Kata thalaq (talak) berasal dari bahasa arab yaitu ithlaq, yang berarti "melepaskan" atau "meninggalkan". Dalam istilah fiqih berarti pelepasan ikatan perkawinan, yakni perceraian antara suami isteri.

Perceraian merupakan bagian yang tidak terpisahkan dari perkawinan, karena itu perceraian senantiasa diatur oleh hukum perkawinan. Hukum perkawinan yang berlaku di Indonesia tidak hanya satu macam tetapi berlaku berbagai peraturan untuk berbagai golongan warga negara dan untuk berbagai daerah (Wirjono, 1984:10).

Cerai adalah sebuah ungkapan dari suatu perbuatan yang memisahkan hubungan antara suami dengan isteri dengan segala akibat hukumnya. Cerai kata yang sederhana bahkan amat sederhana, akan tetapi di dalamnya tersimpan cerita penderitaan yang panjang, betapa tidak nyamannya menyandang predikat janda atau duda cerai, betapa sepi lenggangnya hidup sendirian, dan cerita tentang anak-anaknya yang hidup dalam suasana dan masa depan tak menentu. Sebab kalau dalam keluarga mengalami perpecahan, hal itu jelas merupakan contoh yang tidak baik bagi anak-anak, mau tidak mau akan membawa pengaruh, baik bagi keluarga mereka dimasa yang akan datang. 
Walaupun mereka telah mengetahui akibatnya, namun demikian tidak jarang pasangan suami isteri mereka datang ke Pengadilan Agama minta diceraikan dengan berbagai alasan untuk memenuhi keinginannya. Misalnya masalah pertengkaran yang terjadi setiap saat di antara pasangan suami isteri tersebut.

Perceraian adalah penghapusan perkawinan dengan putusan hakim, atau tuntutan salah satu pihak dalam perkawinan itu (Subekti, 1980:42). Perceraian juga adalah cerai hidup antara pasangan suami istri sebagai akibat dari kegagalan mereka menjalankan obligasi peran masing-masing. Dalam hal ini perceraian dilihat sebagai akhir dari suatu ketidakstabilan perkawinan dimana pasangan suami istri kemudian hidup terpisah dan secara resmi diakui oleh hukum yang berlaku.

Perceraian menurut syara' ialah melepaskan ikatan perkawinan dengan mengucapkan lafadz thalaq atau yang semakna dengannya. Perceraian yaitu putusnya hubungan perkawinan secara hukum yang disebabkan pada hubungan pernikahan yang tidak berjalan dengan baik yang biasanya didahului oleh konflik antar pasangan suami istri yang pada akhirnya mengawali berbagai perubahan emosi, psikologis, lingkungan dan anggota keluarga serta dapat menimbulkan perasaan yang mendalam.

Dalam pengkajian fiqih tentang talak atau perceraian yang bersumber dari hadits yang diriwayatkan oleh Abu Daud dan Ibnu Majah, mengatakan bahwa talak adalah melepaskan ikatan, yaitu melepaskan ikatan perkawinan dengan mengucapkan secara sukarela ucapan talak kepada isterinya, dengan kata-kata yang jelas ataupun dengan kata-kata sindiran (Harahap, 1990:230). Sedangkan dalam Kompilasi Hukum Islam yang dimaksud talak adalah ikrar suami dihadapan sidang Pengadilan Agama yang menjadi salah satu sebab putusnya perkawinan.

Pasal 114 Kompilasi Hukum Islam menyebutkan bahwa putusnya perkawinan yang disebabkan karena perceraian dapat terjadi karena talak atau karena gugatan perceraian. Yang dimaksud cerai talak adalah perceraian yang diajukan oleh laki-laki sedangkan yang dimaksud gugat perceraian atau cerai gugat adalah pihak isteri yang bertindak sebagai penggugat dan suami sebagai tergugat.

Dalam Pasal 38 UU No 1 Tahun 1974 yang menyebutkan sebagai berikut: "perkawinan putus karena kematian, perceraian dan putusan pengadilan". Dalam pasal 39 undang-undang perkawinan diterangkan bahwa perceraian hanya dapat dilakukan didepan sidang pengadilan. Pasal ini dimaksudkan untuk mengatur talak dalam perkawinan menurut agama Islam dan hal ini sesuai dengan prinsip yang terdapat dalam undangundang perkawinan, prinsip tersebut tercantum dalam penjelasan umum undang-undang perkawinan pada angka 4 huruf (e) yang berbunyi sebagai 
berikut: "karena tujuan perkawinan adalah untuk membentuk keluarga yang bahagia, kekal dan sejahtera, maka undang-undang ini mengandung prinsip untuk mempersukar terjadinya perceraian. Untuk memungkinkan perceraian harus ada alasan-alasan tertentu serta harus dilakukan didepan sidang pengadilan.

Akibat hukum dari putusnya perkawinan karena perceraian. Berdasarkan Undang - Undang Nomor 1 Tahun 1974 tentang Perkawinan dalam Pasal 41 disebutkan bahwa akibat dari putusnya suatu perkawinan adalah:

1) Baik ibu atau bapak tetap berkewajiban memelihara dan mendidik anak-anaknya, semata-mata berdasarkan kepentingan anak, bilamana ada perselisihan mengenai penguasaan anak-anak, Pengadilan memberi keputusannya.

2) Bapak yang bertanggung jawab atas semua biaya pemeliharaan dan pendidikan yang diperlukan anak itu, bilamana bapak dalam kenyataannya tidak dapat memberi kewajiban tersebut pengadilan dapat menentukan bahwa ikut memikul biaya tersebut.

3) Pengadilan dapat mewajibkan kepada bekas suami untuk memberikan biaya penghidupan dan/atau menentukan sesuatu kewajiban bagi bekas isteri. Berdasarkan Pasal 41 UU Perkawinan yang telah kami kutip di atas, maka jelas bahwa meskipun suatu perkawinan sudah putus karena perceraian, tidaklah mengakibatkan hubungan antara orang tua (suami dan isteri yang telah bercerai) dan anak-anak yang lahir dari perkawinan tersebut menjadi putus. Sebab dengan tegas diatur bahwa suami dan istri yang telah bercerai tetap mempunyai kewajiban sebagai orang tua yaitu untuk memelihara dan mendidik anak-anaknya, termasuk dalam hal pembiayaan yang timbul dari pemeliharaan dan pendidikan dari anaktersebut. Ketentuan di atas juga menegaskan bahwa Negara melalui UU Perkawinan tersebut telah memberikan perlindungan hukum bagi kepentingan anak-anak yang perkawinan orang tuanya putus karena perceraian.

Walaupun di Indonesia hukum perkawinan beraneka ragam, tetapi pada prinsipnya semua agama yang ada di Indonesia tidak menghendaki adanya perceraian. Namun demikian perceraian kadang-kadang merupakan suatu cara yang baik bagi mereka yang tidak dapat mempertahankan rumah tangganya untuk kebahagiaan dan keselamatan bersama. Oleh karena itu, negara mengatur hal-hal yang tidak diatur hukumnya dalam agama tentang perceraian disamping perkawinan.

Firman Allah Q.S An-Nisaa ayat 19, “Hai orang-orang yang beriman, tidak halal bagi kamu mempusakai wanita dengan jalan paksa dan janganlah kamu menyusahkan mereka karena hendak mengambil kembali sebagian dari apa yang telah kamu berikan kepadanya, terkecuali bila 
mereka melakukan pekerjaan keji yang nyata. Dan bergaullah dengan mereka secara patut. Kemudian bila kamu tidak menyukai mereka, (maka bersabarlah) karena mungkin kamu tidak menyukai sesuatu, padahal Allah menjadikan padanya kebaikan yang banyak". (Q.S. An-Nisaa, 04: 19).

\section{Dasar Hukum Perceraian}

Q.S An-Nisaa ayat 130, "Keduanya bercerai, maka Allah akan memberi kecukupan kepada masing- masing dari limpahan karunia-Nya, dan Allah Maha Kuat (karunia-Nya) lagi Maha Bijaksana". (Q.S. An-Nisaa, 04: 130).

Ayat di atas menjelaskan jika dalam perceraian harus ditempuh sebagai alternatif atau jalan terakhir, maka Allah akan mencukupkan karunia-Nya kepada masing-masing keduanya (suami isteri). Walaupun pasangan suami isteri sudah di akhiri dengan perceraian, namun Islam tetap memberikan jalan kembali bila kedua belah pihak menghendakinya, dengan catatan talak yang di lakukan bukan bain kubro. Talak (yang dapat dirujuk) dua kali setelah itu boleh rujuk lagi dengan cara ma'ruf atau menceraikan dengan cara baik. Keterangan ini menerangkan bahwa ketentuan talak yang masih dapat dirujuk oleh suami adalah sebanyak dua kali, maka apabila suami mentalak lagi (ketiga kalinya) maka tidak halal lagi baginya (suami) untuk merujuk isterinya lagi, kecuali si isteri telah menikah lagi dengan orang lain dan telah bercerai.

Perceraian di Indonesia secara umum diatur dalam undang undang Nomor 1 tahun 1974 pasal 38 - 44, PP Nomor 9 tahun 1975 pasal 14- 36, dan Kompilasi Hukum Islam pasal 113 sampai dengan pasal 148.

\section{Alasan Perceraian}

Undang-undang tidak membolehkan perceraian dengan mufakat saja antara suami dan istri, tetapi harus ada alasan yang sah. Alasan-alasan ini ada empat macam; zina, ditinggalkan dengan sengaja, penghukuman yang melebihi lima tahun karena dipersalahkan melakukan suatu kejahatan, dan penganiayaan berat atau membahayakan jiwa (Pasal 209 B.W.).

Undang-undang perkawinan Pasal 19 PP Nomor 9 Tahun 1975 menambah dua alasan, yaitu:

1) Salah satu pihak mendapat cacat badan atau penyakit dengan akibat tidak dapat menjalankan kewajibannya sebagai suami atau istri.

2) Antara suami istri terus-menerus terjadi perselisihan atau pertengkaran dan tidak ada harapan akan hidup rukun lagi dalam rumah tangga.

Lebih lengkapnya, alasan-alasan ini tercakup lebih rinci dalam Undang-undang pasal 39 ayat 2 jo PP No 9 pada pasal 19: 
1) Salah satu pihak berbuat zina atau menjadi pemabok, pemadat, penjudi, dan lain sebagainya yang sukar disembuhkan.

2) Salah satu pihak meninggalkan pihak lain selama 2 (dua) tahun berturut-turut tanpa izin pihak lain dan tanpa alasan yang sah atau karena hal lain diluar kemampuannya.

3) Salah satu pihak mendapat hukuman penjara 5 (lima) tahun atau hukuman yang lebih berat setelah perkawinan berlangsung.

4) Salah satu pihak melakukan kekejaman atau penganiayaan berat yang membahayakan pihak yang lain.

5) Salah satu pihak mendapat cacat badan atau penyakit dengan akibat tidak dapat menjalankan kewajibannya sebagai suami atau istri.

6) Antara suami dan isteri terus-menerus terjadi perselisihan dan pertengkaran dan tidak ada harapan akan hidup rukun lagi dalam rumah tangga.

\section{Konsep Hadhanah}

Hadhanah menurut pengertian para ulama artinya melakukan pemeliharaan anak-anak yang masih kecil laki-laki atau perempuan atau anak dungu yang tidak dapat membedakan sesuatu dan belum dapat berdiri sendiri, menjaga kepentingan anak melindunginya dari segala yang membahayakan dirinya, mendidik jasmani, rohani, serta akalnya, supaya anak dapat berkembang dan dapat mengatasi persoalan hidup yang akan dihadapinya (Al-Hamdani, 1989:260).

Hadhanah juga yaitu melakukan pemeliharaan anak-anak yang masih kecil laki-laki atau perempuan atau anak-anak yang sudah besar tetapi belum tamyiz (berakal), tanpa perintah dari padanya, menyediakan sesuatu yang menjadi kebaikan baginya, menjaganya dari sesuatu yang menyakiti dan merusaknya, mendidik jasmani, rohani dan akalnya sehingga mampu berdiri sendiri menghadapi hidup dan memikul tanggung jawab (Asmayani, 2013:3).

Maksud hadhanah disini ialah menjaga, memimpin dan mengatur segala hal anak-anak yang belum dapat menjaga dan mengatur dirinya sendiri. Dan apabila terjadi perceraian antara suami isteri, baik dengan jalan thalak, khuluk atau fasakh, sedang keduanya mempunyai anak laki-laki atau perempuan yang masih berumur kurang dari tujuh tahun, maka anak itu dipelihara dan diasuh oleh ibunya, karena ibu adalah sosok manusia yang penyayang dan sesuai untuk mengasuh anak.

Mengasuh buah hati, terutama yang masih kecil hukumnya wajib, sebab anak kecil memerlukan pengawasan, penjagaan dan perhatian. Mengabaikan pengasuhan mereka sama artinya dengan menghadapkan mereka kepada kebinasaan. Seorang ibu adalah pengasuh dan pendidik pertama dan utama bagi anak-anak. Sekalipun pengasuhan seorang anak dapat dilakukan oleh orang lain, pengasuh atau keluarga misalnya. Tetaplah 
kewajiban mengasuh anak tidak akan gugur darinya. Sebab, ibulah orang yang yang paling kuat ikatan lahir dan batinnya dengan anaknya.

Pengasuhan anak (hadhanah) adalah kewajiban bersama sepasang suami isteri. Seorang ayah, tidak bisa berlepas tangan begitu saja dalam pendidikan dan pengasuhan anaknya. Tugas utama seorang ayah adalah menyediakan nafkah yang cukup untuk buah hati dan isterinya yang mengasuh anaknya. Kewajiban memberi nafkah ini tidak dapat terputus, bahkan pada saat terjadi perceraian sekalipun. Apabila seorang anak masih disusui, kemudian terjadi perceraian, ayahnya tetap disapih. Selanjutnya, menjadi tanggung jawabnya pula untuk tetap memberikan nafkah bagi anak-anaknya hingga mereka dewasa. Selain berkewajiban mengasuh anaknya juga mendidiknya memberi pakaian, makanan, menjaga dari segala macam bahaya, menjaga keselamatan dan kesehatan lahir bathin, jasmani dan rohaninya.

Hak pengasuhan anak pada kasus orang tua yang bercerai, apakah hak asuh itu ada pada ayah atau pada ibunya? Abdullah bin Amr ra. Bercerita, "seorang wanita datang dan bertanya kepada Rasulullah saw, "Ya Rasulullah, sesungguhnya bagi anak laki-lakiku ini perutkulah yang menjadi bejananya, lambungku yang menjadi perlindungannya dan air susuku yang menjadi minumannya. Tetapi tiba-tiba ayahnya merasa berhak untuk mengambilnya dariku. 'Maka, sabda beliau saw 'Engkau lebih berhak terhadapnya (anak), selama engkau belum menikah dengan orang lain." (HR. Ahmad, Abu Daud, Baihaqi, dan Hakim).

Hadits ini memberi penegasan bahwa hak asuh anak memang lebih utama diberikan kepada seorang ibu. Abu Bakar ra. Mengatakan hal ini karena seorang ibu lebih perasa, lebih halus, lebih kasih, lebih mesra, lebih baik dan lebih sayang kepada anak-anaknya. Oleh karena itulah, ibu lebih berhak mengasuh anaknya selama ia belum menikah lagi.

\section{Dasar Hukum Hadhanah}

Dalam hal pemeliharaan anak dan keluarga ini dijelaskan dalam firman Allah Q.S At-Tahrim ayat 6, "Hai orang-orang yang beriman, peliharalah dirimu dan keluargamu dari api neraka yang bahan bakarnya adalah manusia dan batu, penjaganya malaikat-malaikat yang kasar, keras, dan tidak mendurhakai Allah terhadap apa yang diperintahkan-Nya kepada mereka dan selalu mengerjakan apa yang diperintahkan. (Q.S At-Tahriim, 66: 6).

Dalam ayat di atas tersurat bahwa Allah telah menyuruh kepada manusia untuk melaksanakan pemeliharaan terhadap diri dan keluarganya. Dalam hal memelihara anak hukumnya adalah wajib dan mengabaikannya berarti mengantarkan anak ke jurang kehancuran dan hidup tanpa guna. 
Memelihara anak adalah kewajiban bersama ibu dan ayah, karena anak membutuhkan pemeliharaan dan asuhan, kebutuhannya dipenuhi dan diawasi pendidikannya. Orang yang berhak mengasuh anak adalah ibu. Oleh karena itu asuhan sangat diperlukan bagi si anak, maka seorang dapat dipaksa untuk mengasuh anak-anaknya, apabila anak nyata sekali memerlukan asuhan dan tidak ada orang lain, agar pendidikannya tidak tersia-siakan atau terlantar.

Al-hamdani mengungkapkan bahwa apabila hak mengasuh anak (hadhanah) belum ditentukan dan si anak masih mempunyai nenek dan nenek tersebut bersedia mengasuhnya sedangkan ibunya tidak bersedia untuk mengasuhnya, maka hak untuk mengasuhnya gugur. Sebab hadhanah adalah haknya (Al-Hamdani, 1989: 261).

Hadits Riwayat Imam Tirmidzi:

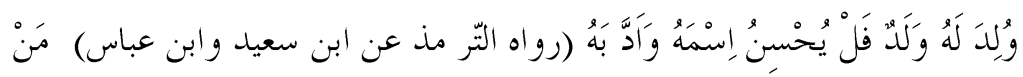

“Jika seseorang dikaruniai anak, hendaknya anak itu diberi nama yang baik dan didiklah dia".

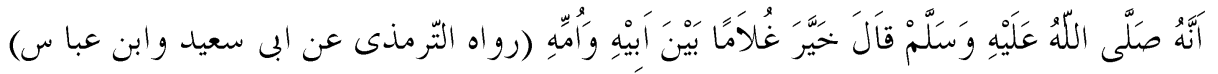

"Sesungguhnya nabi Muhammad saw telah menyuruh seorang anak memilih antara ibunya atau ayahnya".

\section{Ketentuan dan Masa Hadhanah}

Apabila asuhan terhadap anak itu dimulai dari ibu, maka para fuqaha berkesimpulan bahwa kerabat ibu lebih berhak untuk mengasuh dari pada pihak ayahnya. Adapun masa wajib mengasuh yang dilakukan oleh ibunya, Muhammad Rifa'i dalam terjemah kitab Kifayatul Akhyar menjelaskan bahwa ibunya berhak memelihara anaknya sampai umur 7 tahun (Muh. Rifa'i, 1978: 350).

Ini berbeda dengan pendapat yang diungkapkan oleh Sulaiman Rasyid, dimana ia membatasi masa hadhanah, yaitu sampai ia mengerti akan kemaslahatan dirinya. Pada fase itu anak hendaklah bersama ibunya, selama ibunya belum kawin dengan orang lain. Dan apabila anak sudah mengerti, hendaklah diselidiki oleh yang berwajib, siapakah diantara keduanya (ibu atau ayah) yang lebih baik dan lebih pandai untuk mendidik anak itu maka si anak hendaklah diserahkan kepada yang lebih cakap untuk mengatur kemaslahatan anak itu, akan tetapi kalau keduanya sama saja, maka anak itu harus disuruh memilih kepada siapa diantara keduanya di lebih disukai (Sulaeman Rasyid, 1976: 403).

Anak diberi kebebasan untuk memilih antara ikut ayahnya atau ibunya, sebab pada usia itu anak sudah mempunyai kecenderungan (pilihan) siapa yang lebih cocok dia pilih. Para ulama fiqih memberi 
penjelasan mengenai urutan pemeliharaan dalam melaksanakan hadhanah bila ibunya tidak ada, dan ada beberapa syarat yang harus diperhatikan dalam melaksanakan hadhanah tersebut.

Jika anak itu sudah berumur 7 tahun (laki-laki) dan 9 tahun (perempuan) maka pengasuhan diserahkan kepada kesepakatan ayah dan ibunya. Jika terjadi pertentangan antara keduanya maka anak tersebut diberi hak memilih. Namun dalam hal ini para ulama berbeda pendapat antara lain seperti Abu Hanifah, dia berpendapat bahwa ayahnya yang lebih berhak karena pilihan anak-anak itu belum dapat dipercaya. Sayyid Sabiq mengomentari bahwa "dalam agama sendiri tidak ada sama sekali dalil umum tentang lebih mendahulukan antara ayah dan ibu dan menyuruh anak untuk memilih apakah memilih ibu atau ayahnya" (Sayyid Sabiq, 1987:160 JilidVIII). Sedangkan Ibn Qayim berpendapat "Sesungguhnya kita serahkan anak kepada ayah atau ibunya adalah karena mementingkan kemaslahatan anak. Kalau anak tinggal beserta ibunya itu lebih maslahat, maka ia diserahkan kepada ibunya meskipun anak itu memilih ayahnya, karena memang pilihan anak itu belum tepat, sering kali salah pilih (Mahmud Yunus, 1983: 147).

Dan dimanapun anak itu dipelihara, biaya kehidupan anak tersebut tetap menjadi tanggung jawab ayahnya, "Ayah memikul biaya untuk memelihara dan mendidik anak sampai mereka dewasa (Mahmud Yunus, 1983: 146).

\section{a. Urutan Orang yang Berhak Mengasuh Anak}

Para ulama fikih juga menyusun urutan pihak-pihak yang dapat mengasuh anak itu dimulai dari ibu. Urutan tersebut sebagai berikut:

1) Ibu. Apabila terdapat halangan yang menyebabkan ia tidak didahulukan untuk mengsuh anak, maka haknya berpindah kepada:

2) Nenek (ibu dari ibu si anak), apabila ada halangan maka berpindah kepada:

3) Nenek dari pihak ayah si anak, atau seterusnya kepada:

4) Bila nenek dari pihak ibu tidak bisa barulah berpindah kepada ayah

5) Saudara perempuan kandungnya ayah

6) Saudara perempuan seayahnya ayah

7) Keponakan perempuan (anak dari saudara sekandung) ayah

8) Keponakan perempuan (anak dari saudara seibu) ayah

9) Saudara perempuan kandungnya ibu

10) Saudara perempuan seibunya ayah

11) Saudara perempuan seayahnya ayah

12) Keponakan perempuan (anak dari saudara perempuan ibu yang seayah)

13) Keponakan perempuan (anak dari saudara laki-laki sekandung ibu)

14) Keponakan perempuan (anak dari saudara laki-laki seibunya ibu) 
15) Keponakan perempuan (anak dari saudara laki-laki seayahnya ibu)

16) Bibi dari ibu yang sekandung

17) Bibi dari ibu yang seibu

18) Bibi dari ibu yang seayah

19) Bibinya ibu

20) Bibinya ayah

21) Bibinya ibu dari ayahnya ibu

22) Bibinya ayah dari ayahnya ayah

Apabila ternyata anak tidak lagi mempunyai dari muhrim-muhrim tersebut atau ada, tetapi tidak cakap untuk mengasuh anak, maka hak untuk mengasuh anak berpindah kepada ashabah dari pihak-pihak laki-laki menurut tertib dalam bab waris. Apabila tidak ada seorangpun ashabah dari pihak laki-laki atau ada, tetapi tidak cakap untuk mengasuh anak, maka halnya berpindah kepada kerabat laki-laki yang bukan ashabah (AlHamdani, 1980: 263).

Apabila seluruh keluarganya tidak ada yang sanggup, kemungkinan ini rasanya sangat kecil, pengadilan berhak memutuskan siapa yang bertanggung jawab untuk mengambil tanggung jawab pengasuhan ini. Seorang hadhinah (pengasuh), harus memenuhi syarat tertentu agar tugasnya bisa berjalan dengan baik. Bila satu saja syaratnya tidak terpenuhi, ia tidak boleh mengasuh anak tersebut.

b. Syarat-syarat Hadhanah

1) Berakal sehat, tidak gila dan dapat mengurus dirinya serta anak yang hendak diasuhnya.

2) Sudah dewasa. Orang dewasa memiliki kemampuan untuk melakukan berbagai tugas dalam pengasuhan anak, sementara seseorang yang berakal sehat saja, tetapi belum dewasa tetaplah memerlukan bantuan orang dewasa lainnya untuk mengurusi beberapa hal.

3) Mampu mendidik anak, termasuk dalam hal ini adalah memiliki kemampuan fisik. Tidak buta atau rabun, tidak mengidap penyakit menular, tidak lemah secara fisik, sehat secara psikologis, tidak terganggu jiwanya, dan tidak labil emosinya sehingga dapat membahayakan anak.

4) Amanah dan berakhlak baik. Hal ini sangat diupayakan agar anak yang dirawatnya mendapatkan contoh yang baik dari pengasuhnya. Apabila tidak dapat terpenuhi, setidaknya diupayakan mencari orang yang mendekati itu.

5) Mempunyai sifat jujur dan rasa kasih sayang.

6) Beragama Islam. Seorang anak kecil muslim tidak boleh diasuh oleh non muslim. 
7) Belum menikah dengan laki-laki lain.

Mengenai syarat ini, ada pendapat yang mengatakan bahwa apabila suami ibu anak (ayah tiri) yang baru adalah kerabat mahram anak, misalnya pamannya yang cukup mempunyai perhatian besar terhadap pendidikan kemenakan yang kemudian menjadi anak tirinya itu, hak ibu untuk mengasuh anak tidak menjadi gugur sebab paman termasuk yang mempunyai hak mengasuh juga. Berbeda halnya apabila ibu anak kawin dengan laki-laki lain yang tidak mempunyai hubungan kerabat dengan anak.

Dalam hal yang akhir ini hak mengasuh anak terlepas dari ibu, dipindahkan kepada ayah atau lainnya yang lebih mampu mendidik anak tersebut. Namun apabila suami yang baru atau ayah tiri anak bila ia justru menunjukkan perhatiannya yang amat besar untuk suksesnya pendidikan anak. Apabila hal ini terjadi, hak ibu mengasuh tetap ada.

8) Bertempat tinggal

Pengasuhan anak akan berhenti bila sianak sudah tidak lagi memerlukan pelayanan dari orang tua. Anak sudah dewasa, mampu mandiri, dan mampu mengurus dirinya sendiri. Ulama Hanafi berpendapat, masa hadhanah berakhir apabila anak telah berusia 7 tahun untuk anak lakilaki dan 9 tahun untuk anak perempuan. Masa hadhanah anak perempuan lebih lama karena ia masih memerlukan pengasuh untuk membimbingnya memasuki masa balig.

\section{Pendidikan Anak Dalam Keluarga}

Sebagai amanat Allah, anak harus dididik dengan baik, orang tua wajib mendidiknya secara baik sesuai dengan tingkat perkembangan pemikirannya. Sehinga menjadi manusia seutuhnya, manusia yang mengetahui akan hak dan kewajiban hidupnya, baik hak dan kewajiban dirinya terhadap orang tuanya, terhadap masyarakat maupun terhadap Tuhan-Nya.

Tanpa pendidikan yang baik, anak tidak akan berkembang dengan baik, ia tidak akan mengenal tuhan-Nya, tidak akan mengetahui apa hak dan kewajibannya terhadap orang tua dan terhadap masyarakat sekelilingnya. Ia akan menyusahkan orang tuanya, juga meresahkan masyarakat. Allah telah memberikan peringatan kepada orang tua, bahwa harta dan anak-anak adalah fitnah. Tetapi bila harta dibelanjakan dijalan yang benar dan anak dididik hingga menjadi anak yang shalih, maka orang tua akan memperoleh pahala yang besar dari sisi Allah. Hal ini sesuai dengan firman Allah dalam Q.S Al-Anfaal ayat 28, “Dan Ketahuilah, bahwa hartamu dan anak-anakmu itu hanyalah sebagai cobaan dan Sesungguhnya di sisi Allah-lah pahala yang besar". (Q.S Al-Anfaal, 08: 28) 
Orang tua wajib mendidik anak-anaknya dan membiayai selama pendidikannya dan bila terjadi perceraipun, maka kewajiban untuk mendidik dan membiayainya tetap ada dan ayahnya dan ia harus menanggung biayanya sesuai dengan kemampuannya. Pendidikan dasar yang harus diberikan adalah pendidikan tentang baca tulis, akidah yang benar, cara-cara ibadah, akhlak karimah dan pendidikan lain yang juga diperlukan. Juga sebagai orang tua muslim, maka selayaknya apabila pokok-pokok pendidikan yang diajarkan kepada anak-anaknya adalah pokok-pokok ajaran Islam itu sendiri.

Islam adalah agama yang mengajarkan seluruh aspek kehidupan manusia. Mulai masalah yang terkecil sampai masalah yang terbesar, tidak sesuatu pun yang terselip, hal ini dapat dilihat dari fungsi Al-Qur'an. Allah menjelaskan dalam Q.S An-Nahl ayat 89, “(Dan ingatlah) akan hari (ketika) kami bangkitkan pada tiap-tiap umat seorang saksi atas mereka dari mereka sendiri, dan kami datangkan kamu (Muhammad) menjadi saksi atas seluruh umat manusia. Dan kami turunkan kepadamu al-kitab (Al-Qur'an) untuk menjelaskan segala sesuatu dan petunjuk serta rahmat dan kabar gembira bagi orang-orang yang berserah diri". (Q.S An-Nahl, 16: 89)

Adapun pendidikan yang harus diterapkan kepada anak selama ada dalam asuhan orang tuanya adalah mencakup sebagai berikut:

1) Pendidikan yang menanamkan fondasi keimanan

2) Pendidikan moral

3) Pendidikan fisik

4) Pendidikan intelektual

5) Pendidikan yang membentuk psikis anak.

Selain itu ada pokok-pokok ajaran Islam yang harus ditanamkan kepada anak secara garis besarnya dapat dikelompokkan menjadi tiga aspek, yaitu akidah, ibadah dan akhlak. Tetapi mengingat kehidupan modern seperti sekarang ini persaingan hidup teramat ketat, khususnya dibidang kehidupan ekonomi, padahal kehidupan ekonomi itu sangat berpengaruh terhadap pengalaman ajaran Islam, maka anak-anak juga perlu dididik masalah perekonomian, sehingga diharapkan nantinya anak-anak dapat memilki kemandirian ekonomi, memiliki akidah Islamiyah yang kuat, ta' at menjalankan ibadah dan berakhlak mulia.

Peranan keluarga dalam pendidikan anak meliputi berbagai bidang, antara lain sebagai berikut:

1) Pendidikan Jasmani dan Kesehatan

Keluarga mempunyai peranan penting dalam memelihara dan menolong pertumbuhan jasmani anak-anak, baik fungsinya maupun perkembangannya. Begitu pula dengan pemeliharaan kesehatannya. 
Pemeliharaan pertumbuhan dan kesehatan jasmani dapat dilakukan sejak bayi dalam kandungan, antara lain melalui pemeliharaan kesehatan ibunya. Setelah bayi lahir pemeliharaan pertumbuhan dan kesehatan jasmani dapat dilakukan antara lain dengan cara memberikan air susu ibu selama dua tahun, mencukupi makanan dengan yang halal dan bergizi, melindungi dari sumber penyakit dan membimbing dari berbagai kegiatan motorik untuk menolong peningkatan fungsi-fungsi organ tubuh sesuai dengan perkembangannya (Abu Zakki, 1994:98).

Tugas keluarga dalam memelihara pertumbuhan kesehatan jasmani ini, dalam ajaran Islam merupakan suatu tuntutan Allah sebagaimana terdapat dalam beberapa ayat Al-Qur'an, antara lain Al-Qur'an Surat AlBaqarah ayat 233, "Para ibu hendaklah menyusukan anak-anaknya selama dua tahun penuh, yaitu bagi yang ingin menyempurnakan penyusuan. dan kewajiban ayah memberi makan dan pakaian kepada para ibu dengan cara ma'ruf. Seseorang tidak dibebani melainkan menurut kadar kesanggupannya. Janganlah seorang ibu menderita kesengsaraan karena anaknya dan seorang ayah karena anaknya, dan warispun berkewajiban demikian. Apabila keduanya ingin menyapih (sebelum dua tahun) dengan kerelaan keduanya dan permusyawaratan, maka tidak ada dosa atas keduanya. dan jika kamu ingin anakmu disusukan oleh orang lain, maka tidak ada dosa bagimu apabila kamu memberikan pembayaran menurut yang patut. Bertakwalah kamu kepada Allah dan ketahuilah bahwa Allah Maha melihat apa yang kamu kerjakan. (Q.S Al-Baqarah, 02: 233).

Al-Qur'an Surat Al-A'raf ayat 31, "Hai anak Adam, pakailah pakaianmu yang indah di setiap (memasuki) mesjid, makan dan minumlah, dan janganlah berlebih-lebihan. Sesungguhnya Allah tidak menyukai orangorang yang berlebih-lebihan". (Q.S Al-A'raf, 07: 31).

\section{Pendidikan Akal}

Diantara tugas keluarga dalam pendidikan akal terhadap anakanaknya adalah menolong mereka menemukan sikap, minat, bakat dan kemampuan akalnya serta memperoleh kebiasaan-kebiasaan dan sikap intelektual yang sehat dan melatih indera sebagai alat kemampuan akal tersebut. Cara-cara yang dilakukan keluarga dalam memainkan perannnya dalam pendidikan akal adalah mempersiapkan rumah tangga dengan segala macam perangsang intelektual dan budaya seperti mainan-mainan edukatif, buku-buku, majalah-majalah dan koran-koran yang baik (Abu Zakki, 1994:98).

Dalam hal ini keluarga muslim hendaklah memelihara dan mendidik akal anak-anaknya yang bertitik tolak dari ayat-ayat Al-Qur'an dan AlHadits serta nasihat ulama yang menekankan keutamaan akal dan ilmu dan mengajak manusia merenung dan memikirkan kekuasaan Allah. 
Pendidikan Agama dan Akhlak

Pendidikan agama dan spiritual ini berarti membangkitkan kekuatan dan kesediaan spiritual yang bersifat naluri yang ada pada anak-anak melalui bimbingan agama yang sehat dan mengamalkan ajaran-ajaran serta ucapan-ucapan keagamaan yang benar. Dalam Islam, bahwa pendidikan agama dan akhlak merupakan bidang pendidikan yang harus mendapat perhatian penuh oleh keluarga terhadap anak-anaknya. Kehidupan religius yang dialami dan dibiasakan dalam keluarga sejak anak-anak itu lahir, merupakan pengalaman berharga yang akan sangat menentukan jalan kehidupan anak itu selamanya. Pendidikan keagamaan yang utama dan pertama yang harus diperkenalkan adalah kalimat "tauhid" kemudian ditanamkan kepada anak adalah keteguhan aqidah tauhid (Abu Zakki, 1994:98).

\section{Pendidikan Psikis dan Emosi}

Pendidikan psikis dan emosi merupakan bidang pendidikan yang sangat penting untuk diperhatikan oleh keluarga dalam memelihara dan mendidik anak-anaknya. Melalui pendidikan ini, keluarga dapat menolong anak-anaknya untuk menciptakan pertumbuhan emosi yang sehat dan kematangan jiwa yang sesuai dengan umurnya. Tujuan pendidikan adalah "untuk membentuk menyempurnakan dan menyeimbangkan kepribadian anak. Sehingga manakala anak telah memasuki usia mukallaf dia sanggup melaksanakan kewajiban yang dibebankan pada dirinya dan supaya terhindar dari sifat-sifat minder, penakut, rendah diri (pesimis), hasud dan pemarah" (Abu Zakki, 1994:98).

\section{Pendidikan Sosial}

Pendidikan sosial ini melibatkan terhadap tingkah laku sosial, ekonomi politik dalam rangka menanamkan akidah Islam, yang berusaha meningkatkan iman dan taqwa kepada Allah dan mengejarkan ajaran agama yang mendorong kepada produksi, menghargai waktu, jujur, ikhlas, kasih sayang, tolong menolong dan lain-lain (Abu Zakki, 1994:98).

Demikianlah secara ringkas telah penulis kemukakan berbagai hal mengenai aspek-aspek pendidikan dalam keluarga. Selanjutnya seperti telah dikemukakan pada bagian terdahulu, bahwa penanggung jawab penuh yang bertugas melaksanakan pendidikan keluarga adalah ayah dan ibu. Oleh karena itu, untuk lebih memudahkan memahami persoalan dalam penelitian ini, perlu pula dikemukakan peranan masing-masing (ayah dan ibu) dalam pendidikan keluarga tersebut.

1) Peranan ibu

Dengan lahirnya anak dalam keluarga, peranan ibu semakin komplek, ibu memiliki lebih banyak peranan dan kesempatan dalam mengembangkan anak-anak, karena lebih banyak waktu yang 
dipergunakan bersama anak-anaknya daripada ayah. Bila ibu melakukan tugasnya dengan kasih sayang, maka anak akan memperoleh kepuasan dan dapat mengadakan penyesuaian sosial yang baik. Selain kasih sayang, maka ibu harus juga menyediakan waktu yang cukup untuk dapat bermain-main dengan anaknya.

Ibu adalah tokoh yang mendidik anak-anaknya yang memelihara perkembangannya dan mempengaruhi aktifitas-aktifitas di luar rumah. Ibu merupakan tokoh yang dapat melakukan apa saja bagi anak-anaknya, yang dapat mengurus serta memenuhi kebutuhan fisiknya dengan penuh pengertian. Hal ini dapat terlaksana bila ibu memainkan perannya dengan hangat dan akrab, melalui hubungan komunikasi secara terus menerus dengan anak-anaknya.

2) Peranan ayah

Sebagai pemimpin rumah tangga yang bertanggung jawab dalam kebutuhan ekonomi keluarga, maka pada permulaan kehidupan anak, ayah memiliki kesempatan yang lebih kecil dalam mengembangkan anak-anak. Tetapi walaupun demikian, sosok ayah haruslah menjadi figur bagi anakanaknya, baik sikap maupun perbuatan-perbuatan lainnya.

Dengan meningkatnya usia anak maka peranan ayah semakin besar dan komplek. Ayah sebagai orang yang mengepalai keluarga selalu merupakan tokoh yang memegang otoritas terakhir dalam membuat kepusan-keputusan yang utama. Tokoh ayah merupakan benteng kekuatan, pada siapa anak dan ibu biasanya bergantung. Seorang ayah harus dapat menjadi orang kuat bagi anak-anaknya dan menjadi tempat bertanya bagi mereka. Ia membimbing anak-anaknya untuk berani menghadapi berbagai kehidupan di dunia ini.

Peranan ayah tampak melalui aktifitas-aktifitasnya yang berusaha mengembangkan kemampuan-kemampuan, keahlian-keahlian yang di butuhkan anak, mengarahkan minatnya serta mengembangkan kemampuan intelektualnya melalui sikap dan tingkah laku. Ayah sebagai kepala keluarga, maka anak-anak belajar bertingkah laku sebagai layaknya seorang laki-laki. Tahan menghadapi segala sesuatu, tabah, tidak gampang menangis, tegas dan berani.

Orang tua yang baik harus memiliki kualitas sebagai ayah dan ibu yang menjadi pelindung bagi anak-anaknya. Mereka harus memainkan tugasnya dengan baik. Ayah dan ibu adalah tokoh yang ditiru dan diteladani anak. Mereka merupakan tokoh yang menaruh perhatian bila anak dalam kesulitan atau kesedihan. Hal ini hanya dapat terlaksana dengan baik melalui kesatuan yang serasi antara ayah dan ibu serta keadaan rumah tangga yang harmonis. 
Sebagaimana sudah dimaklumi bahwa semua perintah Allah adalah baik, ia harus ditaati dan dilaksanakan, begitu pula semua larangan Allah adalah buruk, ia harus ditinggalkan. Bahwa hadhanah adalah merupakan ajaran Islam yang harus dilaksanakan oleh orang tua yang mempunyai anak. Adapun nafkah biaya penghidupan bagi anak adalah kewajiban ayah, selama anak itu masih kecil atau belum mumayyiz atau selama si anak masih membutuhkannya.

Apabila ayahnya tidak memberi nafkah kepada anaknya juga ibunya tidak mengurus dan mendidiknya, maka keduanya sudah berlaku dholim baik terhadap dirinya maupun anaknya.

Adapun hikmah hadhanah itu antara lain:

1) Menghindari perbuatan dholim.

2) Sebagai sikap ta'awun dalam membantu segala kebutuhan hidup anak sehingga nasibnya jelas dan baik.

3) Bukti ketaatan dalam melaksanakan syari'at ajaran Islam dan sebagai ibadah "hablum minan naas". Yang akan mendapatkan balasan dari Allah.

4) Memberikan kelapangan yang membebani bekas isterinya dalam mengurus, mendidik, dan memenuhi kebutuhan hidup anaknya.

5) Mengurangi beban penderitaan dan menentramkan perasaan bagi si anak yang masih dalam naungan orang tuanya.

Demikian hikmah hadhanah yang dapat diuraikan disini, begitu sangat berharga dan berguna terutama bagi si anak. Insya Allah bila hadhanah dilaksanakan oleh orang tuanya dengan baik, anak itu akan menjadi anak yang shalih, berpendidikan, terarah dan mempunyai kondisi fisik dan psikis yang sehat.

\section{HASIL PENELITIAN DAN PEMBAHASAN}

Metode ijtihad Ulama Desa Karangampel Kecamatan Baregbeg Kabupaten Ciamis tentang Hak Asuh Anak dari Hasil Perceraian

Berdasarkan data-data yang diperoleh di lapangan dan hasil wawancara mengenai hak asuh anak dari hasil perceraian, ulama Desa Karangampel dengan secara langsung memahami ayat-ayat Al-Qur'an dan as-Sunnah secara tekstual dan kontekstual sesuai dengan pemahaman masing-masing berdasarkan pengkajian terhadap kitab-kitab dan bukubuku yang mereka pelajari ditambah penalaran yang mereka asumsikan dari hasil pembelajaran di pesantren maupun sekolah yang mereka tempuh, dengan mencurahkan seluruh kemampuannya dalam memahami makna demi makna dalam lafadz-lafadz ayat dan hadits-hadits tentang hadhanah. 
Dan didapat keterangan bahwasanya, memelihara anak-anak yang masih kecil laki-laki maupun perempuan atau yang sudah besar tetapi belum mumayyiz dalam pelaksanaannya hadhanah harus mempunyai syaratsyarat bagi yang mengurusnya, yaitu berakal sehat, sudah dewasa, mampu mendidik, amanah dan berakhlak baik, mempunyai sifat jujur dan kasih sayang, beragama islam, belum menikah dengan laki-laki lain dan mempunyai tempat tinggal.

Oleh karena itu sudah seharusnya para orang tua, ayah maupun ibu untuk tetap menjaga anaknya, karena anak itu merupakan titipan Allah yang wajib dipelihara dan dijaga supaya meraih kebahagiaan di dunia dan di akhirat, maka wajib sekali untuk kemaslahatan mereka selama hidupnya.

Analisa pendapat Ulama Desa Karangampel Kecamatan Baregbeg Kabupaten Ciamis tentang Hak Asuh Anak dari Hasil Perceraian

Salah satu tujuan pernikahan adalah membangun rumah tangga untuk mendapatkan keturunan yang sah, yang mampu mewujudkan generasi baru untuk melangsungkan kehidupan manusia, baik buruknya generasi baru tersebut sangat ditentukan oleh pemeliharaan dan pendidikan rohani dan jasmani. Adapun tujuan pernikahan yang lain yaitu, membentuk keluarga yang sakinah, mawaddah dan rahmah. Allah berfirman, "Dan di antara tanda-tanda kekuasaan-Nya ialah dia menciptakan untukmu isteriisteri dari jenismu sendiri, supaya kamu cenderung dan merasa tenteram kepadanya, dan dijadikan-Nya diantaramu rasa kasih dan sayang. Sesungguhnya pada yang demikian itu benar-benar terdapat tanda-tanda bagi kaum yang berfikir (QS. Ar-Ruum, 30: 21).

Berdasarkan data yang diperoleh di lapangan, bahwasannya dalam pelaksanaan hadhanah itu kewajiban orang tua adalah menjaga, merawat dan mendidik anaknya dengan baik. Akan tetapi dalam hal memberikan nafkah kepada anak adalah kewajiban ayah.

Namun banyak fakta di zaman sekarang muncul suatu masalah bahwa terjadinya perceraian mengakibatkan para orang tua mempermasalahkan hak asuh anak (hadhanah). Bahkan dalam penelitian yang saya lakukan, ditemukan kasus-kasus yang mana ayahnya maupun ibunya sama-sama ingin memelihara anak tersebut. Jika sudah demikian, siapa yang lebih berhak untuk memelihara anaknya? Penjelasan tentang yang lebih berhak dalam mengurus anak adalah ibunya. Hal ini diterangkan dalam sebuah hadits yang diriwayatkan oleh Imam Abu Dawud, bahwa Rasulullah telah bersabda kepada seorang ibu yang diceraikan oleh suaminya, bahwa engkaulah yang lebih berhak untuk mendidik anakmu selama engkau belum menikah dengan orang lain. Bila anak itu sudah mengerti (mumayyiz), sebagaimana menurut hadits yang diriwayatkan oleh Imam Tirmidzi: 


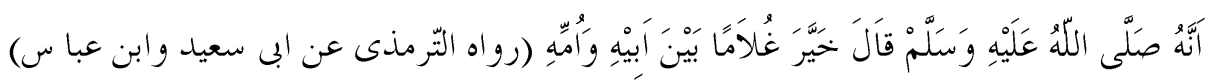

"Sesungguhnya nabi Muhammad saw telah menyuruh seorang anak memilih antara ibunya atau ayahnya". (H.R At-Tirmidzi dari Ibnu Sa'id dan Ibnu Abbas).

Akan tetapi Allah berfirman dalam Q.S An-Nisaa ayat 34, "Kaum laki-laki itu adalah pemimpin bagi kaum wanita, oleh karena Allah telah melebihkan sebahagian mereka (laki-laki) atas sebahagian yang lain (wanita), dan karena mereka (laki-laki) telah menafkahkan sebagian dari harta mereka". (QS. An-Nisa, 04:34).

Menurut ulama Desa Karangampel melihat konteks ayat tersebut bahwa yang dimaksud dengan laki-laki sebagai pemimpin bagi kaum wanita yaitu dalam hal mendidik, memimpin dan mengingatkan jika terjadi penyimpangan. Sementara yang dimaksud dengan melebihkan laki-laki atas wanita yaitu karena ayah diberi kewajiban untuk memberikan nafkah kepada anaknya dan ibu yang menjanda akibat diceraikan suaminya maka ia berhak mendapat nafkah dari suami hingga masa iddahnya berakhir (tiga kali haid) serta upah dalam pengasuhan anak baik dalam masa iddah maupun setelahnya hingga anak mencapai fase tamyiz (berakal) dan melakukan takhyir yang memungkinkan ia untuk memilih ikut ibu atau ayahnya.

Menurut ulama Desa Karangampel, masalah hak asuh anak boleh dilaksanakan oleh ayahnya maupun ibunya. asalkan harus sesuai dengan keinginan anak tersebut. Karena nabi Muhammad saw juga telah menyuruh seorang anak untuk memilih antara ayahnya ataupun ibunya. Asalkan dalam pemeliharaan anak tersebut ayah ataupun ibunya berkewajiban dan bertanggung jawab atas pemeliharaan, pendidikan, bimbingan serta biaya terhadap anak hingga mereka dewasa.

Mengenai hal tersebut penulis menyetujui pendapat para ulama Desa Karangampel di antaranya yaitu wajib bagi para orang tua, ayah maupun ibunya dalam memelihara dan mendidik anaknya dengan baik, karena anak itu merupakan titipan yang wajib dipelihara dan dijaga supaya meraih kebahagiaan di dunia dan di akhirat, maka dalam pelaksanaannya hadhanah wajib dilakukan untuk kemaslahatan anak tersebut selama masa hidupnya.

Menurut penulis jika seorang ayah maupun ibu yang akan mengasuh anaknya, maka dia harus disertai beberapa syarat, yaitu; harus berakal sehat, tidak gila dan dapat mengurus dirinya serta anak yang hendak diasuhnya. Harus beragama Islam, seorang anak kecil muslim tidak boleh diasuh oleh non muslim. 
Dia juga harus sudah dewasa karena orang dewasa memiliki kemampuan untuk melakukan berbagai tugas dalam pengasuhan anak, sementara seseorang yang berakal sehat saja, tetapi belum dewasa tetaplah memerlukan bantuan orang dewasa lainnya untuk mengurusi beberapa hal. Kemudian mampu mendidik anak, termasuk dalam hal ini adalah memiliki kemampuan fisik. Tidak buta atau rabun, tidak mengidap penyakit menular, tidak lemah secara fisik, sehat secara psikologis, tidak terganggu jiwanya, dan tidak labil emosinya sehingga dapat membahayakan anak. Mempunyai sifat amanah dan berakhlak baik, hal ini sangat diupayakan agar anak yang dirawatnya mendapatkan contoh yang baik dari pengasuhnya.

Apabila tidak dapat terpenuhi, setidaknya diupayakan mencari orang yang mendekati itu. Mempunyai sifat jujur dan rasa kasih sayang. Beragama Islam. Seorang anak kecil muslim tidak boleh diasuh oleh non muslim. Kemudian belum kawin dengan laki-laki lain. Mengenai syarat ini, ada pendapat yang mengatakan bahwa apabila suami ibu anak (ayah tiri) yang baru adalah kerabat mahram anak, misalnya pamannya yang cukup mempunyai perhatian besar terhadap pendidikan kemenakan yang kemudian menjadi anak tirinya itu, hak ibu untuk mengasuh anak tidak menjadi gugur sebab paman termasuk yang mempunyai hak mengasuh juga. Berbeda halnya apabila ibu anak kawin dengan laki-laki lain yang tidak mempunyai hubungan kerabat dengan anak.

Dalam hal yang akhir ini hak mengasuh anak terlepas dari ibu, dipindahkan kepada ayah atau lainnya yang lebih mampu mendidik anak tersebut. Namun apabila suami yang baru atau ayah tiri anak bila ia justru menunjukkan perhatiannya yang amat besar untuk suksesnya pendidikan anak. Apabila hal ini terjadi, hak ibu mengasuh tetap ada. Syarat terakhir adalah bertempat tinggal (Muhammad Rifa'i, 1978:351).

Jadi konsep hak asuh anak dari hasil perceraian menurut pendapat ulama Desa karangampel Kecamatan Baregbeg Kabupaten Ciamis lebih banyak bahwa hak asuh terhadap anaknya yang masih kecil memang lebih utama diberikan kepada seorang ibu, karena seorang ibu itu lebih perasa, lebih halus, lebih kasih, lebih mesra, lebih sayang kepada anak-anaknya, selama ia belum menikah lagi. Dan apabila anak itu sudah dewasa ia dibolehkan untuk memilih ikut dengan ayahnya ataupun ibunya.

\section{KESIMPULAN}

Setelah penulis memberikan pembahasan dari hasil penelitian mengenai pendapat ulama Desa Karangampel Kecamatan Baregbeg Kabupaten Ciamis tentang hak asuh anak dari hasil perceraian, tentunya akan diakhiri dengan beberapa kesimpulan yaitu: (1) Menurut pendapat Ulama Desa Karangampel Kecamatan Baregbeg Kabupaten Ciamis 
mengenai hak asuh anak dari hasil perceraian yaitu lebih banyak bahwa hak asuh terhadap anaknya yang masih kecil memang lebih utama diberikan kepada seorang ibu, karena seorang ibu itu lebih perasa, lebih halus, lebih kasih, lebih mesra, lebih sayang kepada anak-anaknya, selama ia belum menikah lagi. Dan apabila anak itu sudah dewasa ia dibolehkan untuk memilih ikut dengan ayahnya ataupun ibunya. (2) Dasar hukum tentang hak asuh anak dari hasil perceraian menurut pendapat ulama desa karang ampel adalah Al-Qur'an surat At-Tahriim ayat 6 dan al Sunnah. (3) Metode ijitihad yang digunakan oleh ulama desa karangampel mengenai hak asuh anak dari hasil perceraian adalah maslahah mursalah juga mengistinbatkan hukum dari penjelasan ayat Al-Qur'an.

\section{DAFTAR PUSTAKA}

Abdullah, Sulaiman. (2004). Sumber Hukum Islam: Permasalahan dan Fleksibilitasnya. Sinar Grafika, cetakan kedua, Jakarta.

Abu, Zakki. (1994). Kiat Pendidikan Anak Shalih. Rosda Karya, Bandung.

Ahsin, Drs. (2006). Kamus Ilmu ALQURAN, Amzah. Jakarta.

Alhamdani. (1980). Risalah Nikah Hukum Perkawinan Islam. Pustaka Amani, Jakarta.

Anonimous. (2004).Undang-undang Republik Indonesia Nomor 1 Tahun 1974

Tentang Perkawinan dan Kompilasi Hukum Islam. Citra Umbara. Bandung.

Anonimous. (2007). Kamus Umum Bahasa Indonesia. Balai Pustaka.Cetakan ketiga. Jakarta.

Asmayani, Nurul. (2013). Perempuan Bertanya Fikih Menjawab, PT Gramedia Pustaka Utama, Jakarta.

Bakry, Nazar. (1993). Figh dan Ushul Figh. Rajawali Pres, cetakan kesatu, Jakarta.

Bisri, Cik Hasan. ( 1998), Penuntun Penyusunan Rencana Penelitian dan Penulisan Skripsi. Cetakan Pertama, Penerbit Logos, Jakarta.

Jumantoro, Totok. (2009). Kamus Ilmu USHUL FIKIH. Amzah. Jakarta.

Kompilasi Hukum Islam. Cv. Haji Masagung, Jakarta.

LPP IAID, (2014), Panduan Penyusunan Skripsi Di Lingkungan Institut Agama Islam Darussalam, Ciamis. 
Mahmud, Yunus. Hukum Perkawinan Dalam Islam. Hidakarya Agung, Jakarta.

Moleong, Lexy J. (1996). Metodologi Penelitian Kualitatif. Remaja Rosdakarya. Bandung.

Undang-undang Republik Indonesia Nomor 1 Tahun 1947 tentang Perkawinan.

Sabiq, Sayyid. (1990). Fikih Sunnah V11.Terjemahan. M. Talib. Al-Ma'arif, Bandung.

Saebani, Beni Ahmad. (2009). Figh Munakahat (Buku 1). CV.PustakaSetia, Cetakan VI. Bandung.

Sugiyono. (2009). Metode Penelitian Kuantitatif Kualitatif dan RED. Alfabeta, cetakan ke 8, Bandung.

Sulaeman, Rasyid. (1976). Fiqh Islam. Al-Thahiriyah, Jakarta.

Syarifuddin, Amir. (2008. Ushul Figh jilid 2. Kencana Prenada Media Group, cetakan kelima, Jakarta.

Syarifuddin, Amir. (2009). Hukum Perkawinan Islam Di Indonesia: antara figh munakahat dan undang-undang perkawinan. Kencana Prenada Media Group, Edisi 1 cetakan ketiga, Jakarta.

Utsman, Muhammad. (1994). Kitab Fikih Wanita 4 Mazhab, Kunci Iman, Jakarta.

Zainuddin, A dan Jamhari, Muhammad. (1999). Al-Islam 1: Akidah dan Ibadah. Pustaka Setia. Bandung. 
